\title{
Spatiotemporal distribution of the bacterial contamination of agricultural and domestic wastewater discharged to a drainage ditch (Sinaloa, Mexico)
}

\section{Distribución espaciotemporal de la contaminación bacteriana del agua residual agrícola y doméstica descargada a un canal de drenaje (Sinaloa, México)}

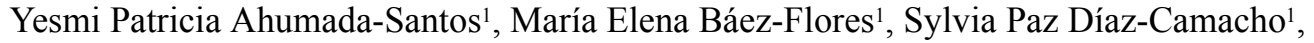 \\ Magdalena de Jesús Uribe-Beltrán ${ }^{1}$, Gabriela López-Angulo ${ }^{1}$, Rito Vega-Aviña ${ }^{2}$, \\ Francisco Armando Chávez-Duran ${ }^{3}$, Julio Montes-Avila1 ${ }^{1}$, Otoniel Carranza-Díaz ${ }^{4}$, Monika Möder ${ }^{4}$, \\ Peter Kuschk ${ }^{5 \dagger}$, Francisco Delgado-Vargas ${ }^{1 *}$ \\ ${ }^{1}$ Facultad de Ciencias Químico Biológicas, Universidad Autónoma de Sinaloa, Ciudad Universitaria \\ s/n, CP 80010 Culiacán, Sinaloa, México. \\ 2 Facultad de Agronomía, UAS, Carretera Culiacán-El Dorado km 17.5, CP 80000 Culiacán, Sinaloa, México. \\ ${ }^{3}$ Comisión Nacional del Agua, Organismo de Cuenca Pacífico Norte, Dirección de Infraestructura \\ Hidroagrícola, Ingeniería de Riego y Drenaje Distrito de Riego 010 Culiacán-Humaya, México. \\ ${ }^{4}$ Department of Analytical Chemistry and ${ }^{5}$ Department of Environmental Biotechnology, UFZ - Helmholtz \\ Centre for Environmental Research, Permoserstr. 15, 04318 Leipzig, Germany. \\ ${ }^{\dagger}$ Peter Kuschk passed away on 14 October 2014, requiescat in pace \\ * Corresponding author: fdelgado@uas.edu.mx; fcodelgadovargas@gmail.com.
}

\begin{abstract}
The agricultural drainage water from the Sinaloa valley (Mexico) is often reused in agriculture and aquaculture before reaching coastal water bodies. Discharged water must be of good quality to maintain the health of ecosystems and prevent damage to the organisms that compose them. This research determined the occurrence of coliforms in a drainage ditch known as La Michoacana (Sinaloa) that receives contaminated water from agricultural and urban sources. A section of $3.6 \mathrm{~km}$ was studied during 2013 and samples were obtained monthly from five equidistant sampling sites. Each water sample was analyzed for total coliform (TC) and fecal coliform (FC) content, pH, salinity, temperature, and dissolved oxygen percentage $(\% \mathrm{DO})$. The sampling sites with the highest bacterial contamination were associated with direct discharges of domestic wastewater and those with the lowest to the output drain. The performance of this agricultural ditch decreased the concentration of coliforms, with median and average values of $96 \%$ and $87 \%$ for TC, and $98 \%$ and $85 \%$ for FC, respectively. The most common bacteria were Escherichia coli (67.7\%), Kluyvera cryocrescens (10.2\%), and Enterobacter agglomerans (6.3\%). Coliform concentration was positively correlated with temperature and negatively with \%DO. The ditch improved the microbiological quality of the water, demonstrating remediation activities in the system. Proper management and maintenance of agricultural drainage ditches would favorably impact the health and biodiversity, as well as the intensive aquaculture and agricultural activities of the Sinaloa valley.
\end{abstract}

Key words: coliforms, agricultural drains, sanitation, water quality, bacteria removal.

RESUMEN. El agua que conducen los canales de drenaje del valle agrícola sinaloense (México) es reutilizada con frecuencia en la agricultura y acuacultura antes de ser depositada en las aguas costeras. La calidad del agua descargada debe ser adecuada para mantener la salud de los ecosistemas y evitar daño a los organismos que los componen. Esta investigación determinó la presencia de coliformes en el canal de drenaje agrícola conocido como La Michoacana (Sinaloa), que recibe agua contaminada de fuentes agrícolas y urbanas. Se estudió una sección de $3.6 \mathrm{~km}$ del canal durante el año 2013 y se recolectaron mensualmente muestras de agua de cinco puntos de muestreo equidistantes. A cada muestra se le analizó el contenido de coliformes totales $(\mathrm{CT})$ y coliformes fecales $(\mathrm{CF}), \mathrm{pH}$, salinidad, temperatura y porcentaje de saturación de oxígeno disuelto (\%OD). Los puntos de muestreo con mayor contaminación bacteriana estuvieron asociados a las descargas directas de agua residual doméstica, y aquellos con menor contaminación estuvieron asociados a la salida del canal de drenaje. El funcionamiento del canal disminuyó la carga de coliformes, con medianas y valores promedio del $96 \%$ y $87 \%$ para CT, y $98 \%$ y $85 \%$ para CF, respectivamente. Las principales bacterias identificadas fueron Escherichia coli (67.7\%), Kluyvera cryocrescens (10.2\%) y Enterobacter agglomerans (6.3\%). La concentración de coliformes presentó una correlación positiva con la temperatura y negativa con el \%OD. El canal de drenaje La Michoacana mejora la calidad microbiológica del agua que conduce, lo cual demuestra funciones de remediación en el sistema. El mantenimiento y manejo adecuado de los canales de drenaje agrícola puede impactar favorablemente la salud y biodiversidad, así como las actividades acuícolas y agrícolas intensivas del valle sinaloense.

Palabras clave: coliformes, drenaje agrícola, saneamiento, calidad del agua, remoción bacteriana. 


\section{INTRODUCTION}

Water is essential to life, but frequently polluted by anthropogenic activities (e.g., domestic, industrial, and agricultural). In developing countries, $80 \%$ of the sewage is discharged untreated into water bodies, which also receive 300 to $400 \mathrm{t} \mathrm{yr}^{-1}$ of industrial wastes. Water pollution contributes to the degradation of ecosystems, loss of biodiversity, and development of diseases, and causes the death of approximately 3.5 million people annually (ONU-DAES and UNwater 2014). Consequently, effective and inexpensive water treatments (i.e., those that eliminate chemical and biological contaminants) are required.

Wetlands (natural or constructed) provide, with low technical effort, overall benefits to the environment and human health (Pierre and Finlayson 2011, Alexander and McInnes 2012). Studies have shown that wetlands improve the quality of the drained water. By acting as biofilters, wetlands remove chemical and biological contaminants (e.g., pathogenic bacteria) by diverse physical, chemical, and biological processes (Kadlec and Wallace 2009, Reinoso et al. 2008, Azaizeh et al. 2012, Lekeufack et al. 2012, Rühmland and Barjenbruch 2012).

Fecal coliforms, found in the intestine and feces of animals, are indicators of pollution and consequently of water quality, and thus warn about the possible presence of human pathogens. The presence of fecal coliforms in aquatic environments may be due to the abundant incorporation of water contaminated by sewage and other organic wastes from anthropogenic activities (Cupul-Magaña et al. 2006, Bagordo et al. 2012, Sidhu et al. 2012, Barrera-Escorcia et al. 2013, Ochoa-Izaguirre and Soto-Jiménez 2013, Valdés et al. 2014, Wu et al. 2014).

Agriculture is the main economic activity of Sinaloa State, which has $838,278.58$ ha of irrigated land $(\cong 14.5 \%$ of Mexico's irrigated land). In 2013, the production value was US\$2184 million (SIAP 2014). Agricultural activities in Sinaloa require a lot of human labor. In $2004,30 \%$ of the Mexican migrant workers $(72,000)$ seeked employment in the Sinaloa agricultural fields. Most migrant workers live on site in small townships (Ramírez-Romero et al. 2006). The infrastructure of Sinaloa includes $8548.5 \mathrm{~km}$ of agricultural drainage ditches, and the presence of human communities alongside them is common; consequently, they often receive highly contaminated water (e.g., sewage and wastewater from nearby rural communities and crop irrigation). The drained water is reused downstream to irrigate crops, as a source of water for livestock, and in aquaculture farms located along the course of the stream before being deposited in coastal water bodies; moreover, water in the final disposal areas (e.g., rivers, bays, estuaries) may even be used in human activities (CONAGUA 2011). In addition to agriculture, fishing is another of Sinaloa's primary economic activities. In 2011, the state occupied first place in aquaculture production on the Mexican Pacific coast, contributing

\section{INTRODUCCIÓN}

El agua es indispensable para la vida, sin embargo, las actividades antropogénicas (e.g., domésticas, industriales y agrícolas) frecuentemente la contaminan. En los países en desarrollo, el $80 \%$ de las aguas residuales se descargan sin tratamiento directamente a los cuerpos de agua, los cuales reciben de 300 a $400 \mathrm{t}$ año ${ }^{-1}$ de residuos industriales. La contaminación del agua contribuye a la degradación de los ecosistemas, pérdida de biodiversidad y desarrollo de enfermedades, y ocasiona la muerte de aproximadamente 3.5 millones de personas anualmente (ONU-DAES y UNwater 2014). Este panorama enfatiza la necesidad de contar con tratamientos de agua efectivos (i.e., aquellos que eliminen contaminantes químicos y biológicos) y de bajo costo.

Los humedales (naturales o construidos) proporcionan, con bajo esfuerzo técnico, un beneficio integral al medio ambiente y a la salud humana (Pierre y Finlayson 2011, Alexander y McInnes 2012). Diversos estudios han demostrado el desempeño de los humedales sobre la mejora de la calidad del agua que conducen. Al actuar como biofiltros, los humedales remueven contaminantes químicos y biológicos (e.g., bacterias patógenas) mediante diversos procesos físicos, químicos y biológicos (Kadlec y Wallace 2009, Reinoso et al. 2008, Azaizeh et al. 2012, Lekeufack et al. 2012, Rühmland y Barjenbruch 2012).

Las bacterias coliformes fecales, encontradas en el intestino y heces de animales, son indicadores de contaminación y consecuentemente de la calidad del agua, y advierten así sobre la posible presencia de organismos patógenos que pueden afectar la salud humana. Su presencia en ambientes acuáticos puede deberse a la incorporación abundante de aguas contaminadas con excretas y otros desechos orgánicos derivados de actividades antropogénicas (Cupul-Magaña et al. 2006, Bagordo et al. 2012, Sidhu et al. 2012, BarreraEscorcia et al. 2013, Ochoa Izaguirre y Soto-Jiménez 2013, Valdés et al. 2014, Wu et al. 2014).

La agricultura es la principal actividad económica en el estado de Sinaloa, el cual cuenta con 838,278.58 ha de riego

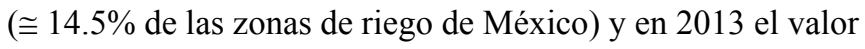
de su producción fue de aproximadamente \$2184 millones de dólares (SIAP 2014). Las actividades agrícolas en Sinaloa demandan una gran cantidad de mano de obra. En 2004, el $30 \%$ de los trabajadores migrantes $(72,000)$ de México llegaron a Sinaloa para emplearse en el campo agrícola, y la mayoría vive en los campos agrícolas en pequeños poblados (Ramírez-Romero et al. 2006). La infraestructura de Sinaloa incluye $8548.5 \mathrm{~km}$ de canales de drenaje agrícola, y es común la presencia de comunidades humanas en su entorno; consecuentemente, los canales reciben con frecuencia aguas altamente contaminadas (e.g., aguas negras y residuales de comunidades rurales cercanas y de riego de cultivos). El agua que conducen estos canales de drenaje es reutilizada corriente abajo en el riego de cultivos, como fuente de agua para 
$57,929 \mathrm{t}(31.09 \%$ of the total aquaculture production on the Mexican Pacific Coast).

Hence, the main economic activities of Sinaloa depend on sufficient water resources and good water quality (CONAPESCA 2012). It is now known that contaminated agricultural drainage water adversely affects aquatic and terrestrial life in Sinaloa (Escobedo-Urías et al. 1999, Haws et al. 2006, Ochoa-Izaguirre and Soto-Jiménez 2013), in Mexico, and around the world (Bagordo et al. 2012, Matano et al. 2013, Riera et al. 2013, Valdés et al. 2014, Wu et al. 2014). On the other hand, agricultural drains can function as artificial surface wetlands and reduce water pollution and its adverse effects, but the drainage flow must be low permitting the presence of aquatic plants (Kadlec and Wallace 2009). Thus, the aim of this study was to analyze the performance of an agricultural drain in reducing the concentrations of coliform bacteria in the drained water.

\section{MATERIALS AND METHODS}

\section{Study area}

The agricultural drainage ditch known as La Michoacana is approximately $6.3 \mathrm{~km}$ long and is located in an area with intense agricultural activity in the municipality of Navolato, Sinaloa, Mexico. This agricultural drain receives irrigation water and rainwater, as well as domestic wastewater and solid wastes from a small community (Colonia Michoacana, 1225 inhabitants) living alongside (SEDESOL 2014). In general, the La Michoacana water flow is intermittent and its bottom vegetation is dominated throughout the year by Typha domingensis. The La Michoacana drainage water is mixed with that from another drain, the Navolato ditch. This water is used for agricultural irrigation in areas near the coast and, approximately $20 \mathrm{~km}$ downstream, for aquaculture, and eventually discharges into the Pacific Ocean. To analyze the water flowing through a section of $3.6 \mathrm{~km}$ of the La Michoacana drain, five equidistant sampling sites (SS) were selected: the

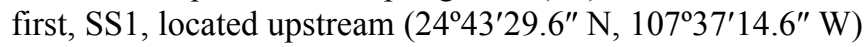
and the last, SS5, located downstream $\left(24^{\circ} 43^{\prime} 20.4^{\prime \prime} \mathrm{N}\right.$, $107^{\circ} 39^{\prime} 21.4^{\prime \prime} \mathrm{W}$ ); SS5 is about $35 \mathrm{~m}$ from the intersection with the Navolato ditch. The studied section of the ditch receives water discharges from four point sources (domestic wastewater) and 16 non-point sources (water from nearby crop areas) (fig. 1).

\section{Water sampling and analysis}

Water samples were collected monthly from March to December 2013. They were taken during the early morning hours using 500-mL sterile bags (Whirl-Pak) at a depth of $15 \mathrm{~cm}$ from the surface. The samples were kept under refrigeration $\left(4^{\circ} \mathrm{C}\right)$ and analyzed within the following $8 \mathrm{~h}$. The presence of total coliforms (TC) and fecal coliforms (FC) was quantified by the membrane filtration technique; the ganado y en granjas acuícolas ubicadas a lo largo del curso del canal antes de ser depositada en cuerpos de agua costeros; incluso, puede utilizarse en actividades con contacto humano en las zonas de depósito final (e.g., ríos, bahías, esteros) (CONAGUA 2011). Al igual que en la agricultura, Sinaloa destaca en la pesca. En 2011, este estado ocupó el primer lugar en producción acuícola del litoral mexicano en el pacífico, con una aportación de 57,929 t (31.09\% de la producción acuícola total de la costa mexicana en el pacífico).

Las principales actividades económicas de Sinaloa dependen de abundates recursos hídricos y de la calidad del agua (CONAPESCA 2012). Hoy en día se conoce que el agua contaminada de los canales de drenaje agrícola afecta de manera negativa la vida acuática y terrestre en Sinaloa (Escobedo-Urías et al. 1999, Haws et al. 2006, Ochoa Izaguirre y Soto-Jiménez 2013), México y el mundo (Bagordo et al. 2012, Matano et al. 2013, Riera et al. 2013, Valdés et al. 2014, Wu et al. 2014). Por otra parte, los canales de drenaje pueden funcionar como humedales artificiales de flujo superficial y disminuir la contaminación del agua y sus efectos negativos, pero éstos deben transportar bajos flujos de agua para favorecer el establecimiento de las plantas acuáticas (Kadlec y Wallace 2009). El objetivo de este trabajo fue analizar la efectividad de un canal de drenaje agrícola en la disminución de las concentraciones de bacterias coliformes en el agua que descarga.

\section{MATERIALES Y MÉTODOS}

\section{Área de estudio}

El canal de drenaje agrícola conocido como La Michoacana tiene una longitud de aproximadamente $6.3 \mathrm{~km}$ y se ubica en un área con intensa actividad agrícola en el municipio de Navolato, Sinaloa, México. Este drenaje recibe agua de escurrimiento de riegos y pluvial, así como agua residual doméstica y desechos sólidos de una pequeña comunidad (Colonia Michoacana, 1225 habitantes) que habita en sus márgenes (SEDESOL 2014). De manera general, La Michoacana transporta flujos intermitentes de agua y la vegetación en el lecho del canal es dominada por Typha domingensis durante todo el año. El agua de La Michoacana se mezcla con la del canal de drenaje Navolato. Esta agua se usa para el riego agrícola en áreas más cercanas a la costa y, aproximadamente a $20 \mathrm{~km}$ corriente abajo, para la acuacultura, y finalmente es vertida en el océano Pacífico. Para analizar el agua que fluye por una sección de $3.6 \mathrm{~km}$ del canal de dreanje La Michoacana, se seleccionaron cinco puntos de muestreo (PM) aproximadamente equidistantes: el punto inicial (PM1) se ubicó corriente arriba $\left(24^{\circ} 43^{\prime} 29.6^{\prime \prime} \mathrm{N}\right.$, $107^{\circ} 37^{\prime} 14.6^{\prime \prime} \mathrm{W}$ ) y el punto final (PM5) corriente abajo

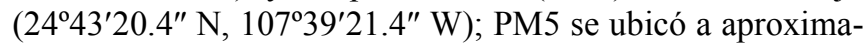
damente $35 \mathrm{~m}$ de la intersección con el canal de drenaje Navolato. La sección estudiada del canal de drenaje recibe cuatro entradas puntuales de agua (descargas residuales 
analyses were carried out in duplicate and under sterile conditions. First, water was homogenized and, if required, diluted with peptone water ( $\mathrm{pH}=7.2$, Difco). Five milliliters of the direct sample or dilution was then filtered through a $0.45 \mu \mathrm{m}$ membrane (Pall Corporation), and the retenate was washed with $50 \mathrm{~mL}$ of sterile distilled water. The membrane was transferred to the culture media m-Endo Agar $(\mathrm{pH}=7.2$, Difco), in the case of TC, and FC Agar ( $\mathrm{pH}=7.4$, Difco), in the case of FC. The plates were incubated for $24 \mathrm{~h}$ at $37^{\circ} \mathrm{C}$ (TC) or $45^{\circ} \mathrm{C}$ (FC). The characteristic colonies that developed on the membrane were counted and the results were expressed as colony forming units (CFU) in $100 \mathrm{~mL}$ of sample (APHA et al. 2005). Culture media treated without the filtrated sample were processed as described and used as control of sterility.

\section{Identification of bacterial strains}

From the quantified coliform bacteria, three to five colonies isolated from each SS per sampling date were selected domésticas) y 16 no puntuales (descargas de áreas de cultivo cercanas) (fig. 1).

\section{Recolección y análisis de muestras de agua}

Se recolectaron muestras de agua mensualmente de marzo a diciembre de 2013. Las muestras fueron tomadas durante las primeras horas de la mañana utilizando bolsas estériles (Whirl-Pak) de $500 \mathrm{~mL}$ y a una profundidad aproximada de $15 \mathrm{~cm}$ de la superficie. Las muestras se mantuvieron en condiciones de refrigeración $\left(4^{\circ} \mathrm{C}\right)$ hasta su análisis dentro de las siguientes $8 \mathrm{~h}$. Se cuantificó la presencia de coliformes totales (CT) y coliformes fecales (CF) empleando la técnica de filtración por membrana; el análisis se realizó por duplicado para cada muestra y en condiciones de esterilidad. Primero, el agua se homogenizó y, en caso necesario, se realizaron diluciones con agua peptonada $(\mathrm{pH}=7.2$, Difco). Luego, se filtró un volumen de $5 \mathrm{~mL}$ de la muestra de agua directa o diluida a través de una membrana con un tamaño de poro de $0.45 \mu \mathrm{m}$ (Pall Corporation), y el residuo se lavó con
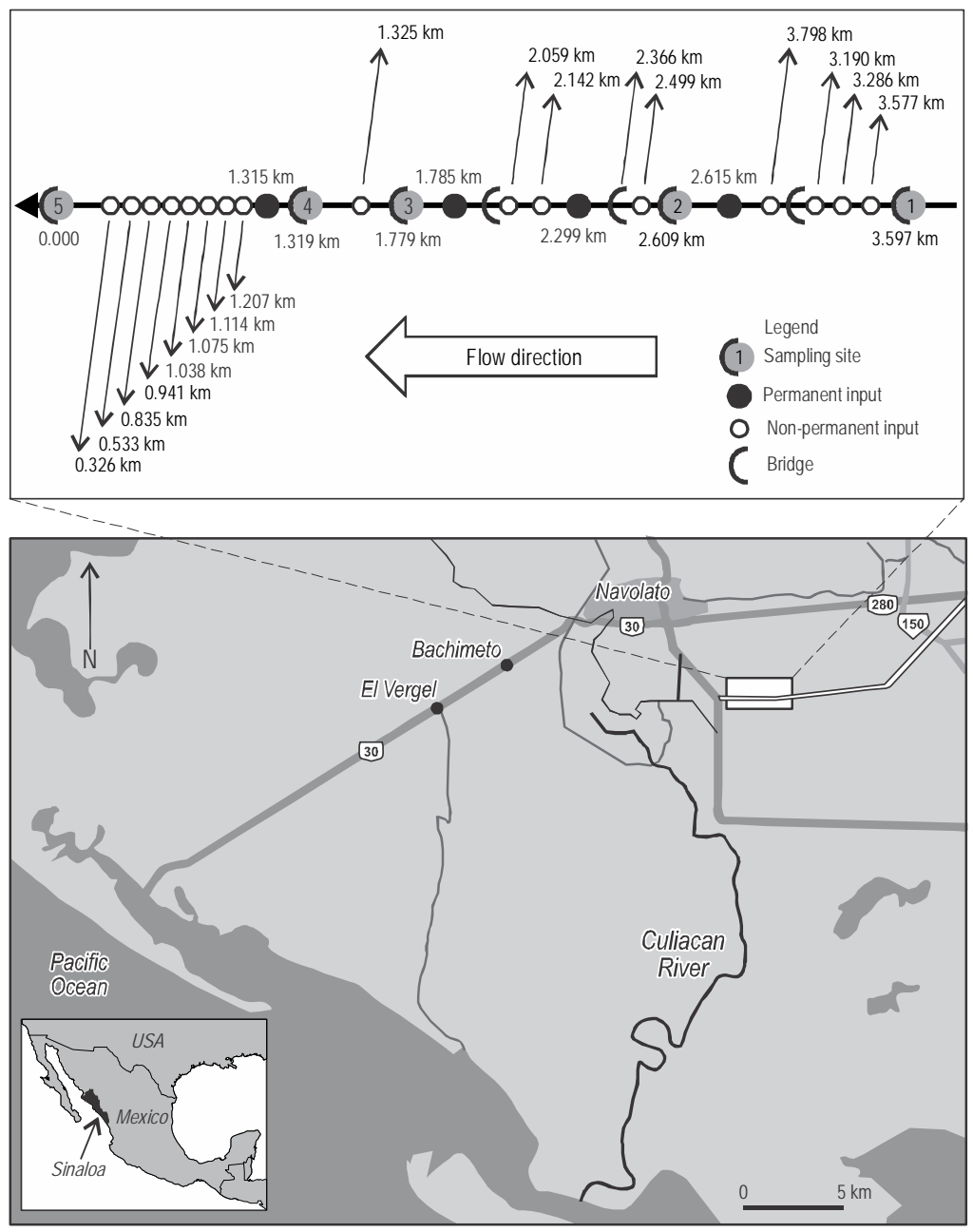

Figure 1. Study area and location of sampling sites.

Figura 1. Área de estudio y localización de los puntos de muestreo. 
for identification using conventional biochemical and physiological tests (use of citrate and malonate as a source of carbon; fermentation of carbohydrates; decarboxylation of amino acids; production of gas, hydrogen sulfide, and indole; and motility) (MacFaddin 2003).

\section{Measurement of physicochemical water parameters}

The $\mathrm{pH}$, salinity, percentage of dissolved oxygen ( $\% \mathrm{DO})$, and temperature $\left({ }^{\circ} \mathrm{C}\right)$ of water at each SS per sampling date were measured in situ with an HI9828 multiparameter meter (Hanna Instruments).

\section{Statistical analysis}

Data were analyzed by analysis of variance (ANOVA) using the factors sampling month and SS. Means were contrasted by the Duncan test $(\alpha=0.05)$, and the correlation between physicochemical water parameters and the TC and FC concentrations was determined by Pearson correlation analysis. The statistical software STATGRAPHICS Plus 5.1 was used.

\section{RESULTS}

The TC and FC concentrations varied with sampling date and site. The concentrations at several SS were higher than at the initial sampling point (SS1) of the drain section. SS2 showed the highest concentrations of TC and FC in $80 \%$ and $60 \%$ of the sampled months, respectively, whereas SS5 had the lowest in $85 \%$ of the sampled months. In relation to temporality, the highest coliform concentrations for the first four sites (SS1-4) were observed in samples in June and July, whereas for SS5 they were recorded in September (fig. 2), month in which Sinaloa was affected by Hurricane Manuel. In contrast, the lowest coliform concentrations for the SS1-4 samples were registered in March and November, and for SS5 in April (fig. 2).

The overall analysis of the studied period showed that SS2 had the highest average coliform concentrations (TC, $3.23 \times 10^{7} \mathrm{CFU} 100 \mathrm{~mL}^{-1}$; FC, $1.77 \times 10^{7} \mathrm{CFU} 100 \mathrm{~mL}^{-1}$ ) and SS5 the lowest (TC, $2.8 \times 10^{4} \mathrm{CFU} 100 \mathrm{~mL}^{-1}$; FC, $5.4 \times$ $10^{3} \mathrm{CFU} 100 \mathrm{~mL}^{-1}$ ) (fig. 3). Statistical differences were registered for July (TC, $P=0.0001 ; \mathrm{FC}, P=0.0037$ ) and SS2 (TC, $P=0.0007 ; \mathrm{FC}, P=0.0257)$. The average percent reductions of coliform concentrations per segment of the analyzed drain section (i.e., SS1 to SS2, SS2 to SS3, SS3 to SS4, and SS4 to SS5) were $-223 \%, 59 \%, 37 \%$, and $62 \%$ for $\mathrm{TC}$, and $-700 \%$, $59 \%, 30 \%$, and $60 \%$ for $\mathrm{FC}$, respectively, where negative values mean increments. On the other hand, the monthly reduction percentages, considering the first (SS1) and last (SS5) sampling points, showed a clear decreasing trend in coliform concentration (fig. 2). Statistical differences were found for 7 of the 10 sampled months $(P<0.05)$. The median and mean values of removal percentages were $96 \%$ and $87 \%$
$50 \mathrm{~mL}$ de agua destilada estéril. La membrana se transfirió a los medios de cultivo Agar m-Endo ( $\mathrm{pH}=7.2$, Difco), en el caso de CT, y Agar FC ( $\mathrm{pH}=7.4$, Difco), en el caso de CF. Las placas fueron incubadas a $37^{\circ} \mathrm{C}(\mathrm{CT})$ o $45^{\circ} \mathrm{C}(\mathrm{CF})$ durante $24 \mathrm{~h}$. Se realizó el recuento directo de colonias características que se desarrollaron sobre la membrana y los resultados se expresaron como unidades formadoras de colonias (UFC) en $100 \mathrm{~mL}$ de muestra (APHA et al. 2005). Medios de cultivo sin muestra filtrada fueron sometidos al mismo proceso como control de esterilidad.

\section{Identificación de cepas bacterianas}

De las bacterias coliformes cuantificadas, se seleccionaron de tres a cinco colonias aisladas de cada PM por fecha de muestreo para su identificación mediante pruebas bioquímicas y fisiológicas convencionales (utilización de citrato y malonato como fuente de carbono; fermentación de carbohidratos; descarboxilación de aminoácidos; producción de gas, ácido sulfhídrico e indol; y movilidad) (MacFaddin 2003).

\section{Medición de parámetros fisicoquímicos del agua}

$\mathrm{El} \mathrm{pH}$, la salinidad, el porcentaje de saturación de oxígeno disuelto $\left(\%\right.$ OD) y la temperatura $\left({ }^{\circ} \mathrm{C}\right)$ del agua de cada PM por fecha de muestreo fueron medidos in situ con un medidor multiparamétrico HI9828 (Hanna Instruments).

\section{Análisis estadístico}

Se realizó un análisis de varianza (ANOVA, por sus siglas en inglés) con los factores mes de muestreo y PM. Las medias fueron comparadas aplicando la prueba de Duncan $(\alpha=0.05)$. Se realizó un análisis de correlación de Pearson entre los parámetros fisicoquímicos del agua y las concentraciones de CT y CF. Los análisis se realizaron con el programa estadístico STATGRAPHICS plus 5.1.

\section{Resultados}

Las concentraciones de CT y CF variaron de acuerdo con la fecha y el punto de muestreo. Las concentraciones en algunos PM fueron mayores que en el punto inicial de muestreo (PM1) de la sección del canal de drenaje. PM2 presentó las mayores concentraciones de CT y CF en el $80 \%$ y $60 \%$ de los meses muestreados, respectivamente, mientras que PM5 presentó las menores concentraciones en el 85\% de los meses muestreados. En relación con la temporalidad, las mayores concentraciones de coliformes para los primeros cuatro puntos (PM1-4) fueron observadas en junio y julio, mientras que para PM5 fueron registradas en septiembre (fig. 2), mes en que Sinaloa fue afectado por el huracán Manuel. En contraste, las menores concentraciones de coliformes para PM1-4 fueron observadas en marzo y noviembre, y para PM5 en abril (fig. 2). 

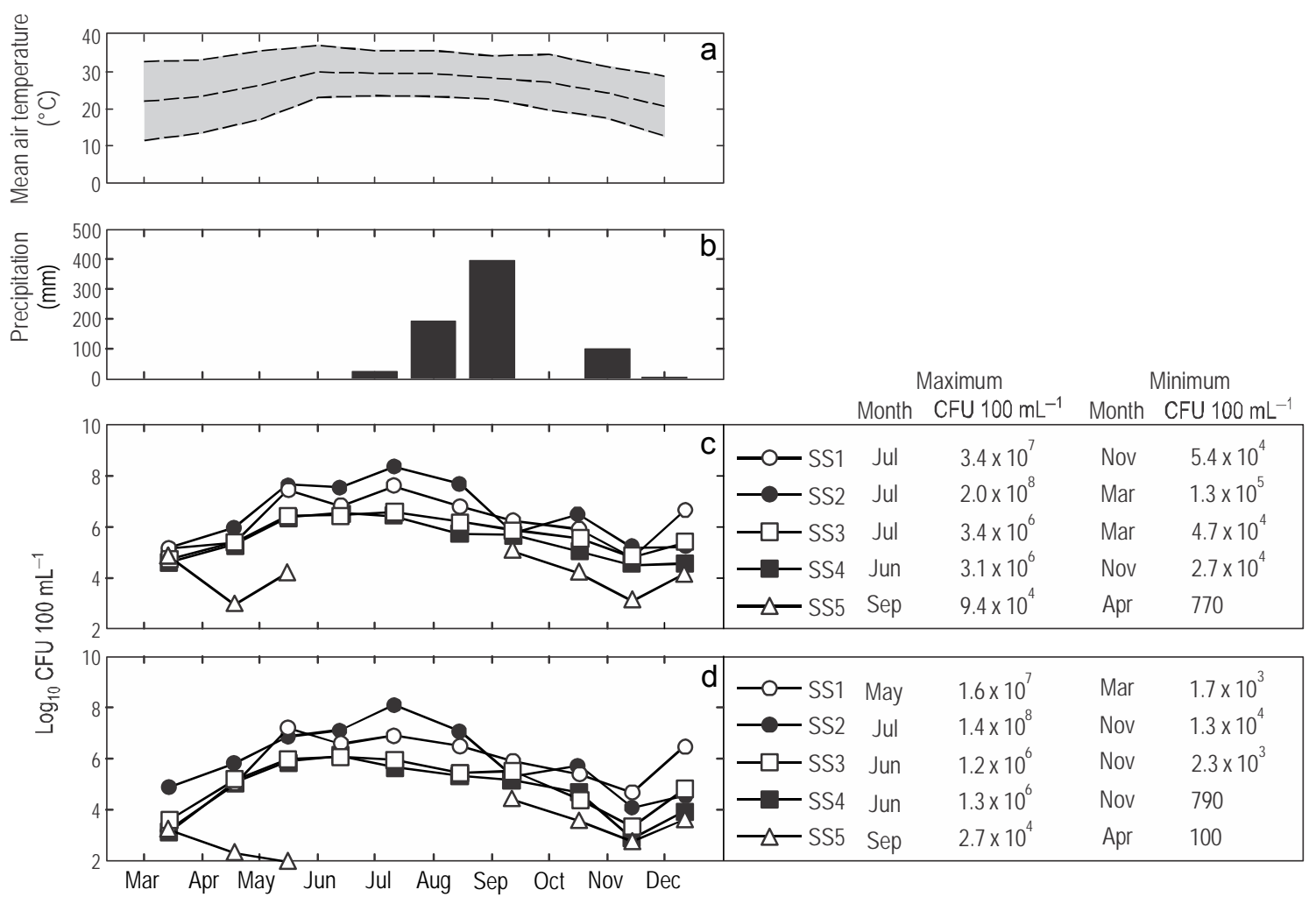

Figure 2. Mean air temperature (a) and rainfall (b) during the study (data obtained from meteorological stations of the National Water Commission, Mexico). Spatial and temporal concentration of total coliforms (c) and fecal coliforms (d) at the sampling sites (SS1-5). In (a), lines correspond to the recorded minimum, maximum, and mean air temperatures, and the shaded area indicates the expected air temperature for the corresponding period.

Figura 2. Temperatura promedio ambiental (a) y precipitación (b) durante la investigación (datos obtenidos de estaciones meteorológicas de la Comisión Nacional del Agua, México). Concentración espacial y temporal de coliformes totales (c) y fecales (d) en los puntos de muestreo (SS1-5). En (a), las líneas corresponden a las temperaturas del aire mínimas, máximas y promedio, y el área sombreada representa las temperatura del aire esperada para el periodo correspondiente.

for TC and $98 \%$ and $85 \%$ for FC, respectively. These results correspond to decreases of 2.42 (TC) and 2.84 (FC) logarithmic units of coliforms along the analyzed drain section (figs. 2, 3).

A total of 127 bacterial strains were identified: Escherichia coli (67.7\%), Kluyvera cryocrescens (10.2\%), Enterobacter agglomerans (6.3\%), Citrobacter amalonaticus (3.9\%), Serratia liquefaciens group (3.1\%), Hafnia alvei (2.4\%), Enterobacter aerogenes (2.4\%), Serratia odorifera (1.6\%), Citrobacter freundii (1.6\%), and Enterobacter sakazakii $(0.8 \%)$. In general, the presence of specific bacterial species did not show any relation to the sampling month; however, E. coli was the only bacterial species identified in the water samples from all SS and sampled months. The other bacteria were not detected in at least one SS or sampled month. In particular, three bacteria were found only at one SS (S. odorifera, SS4; C. freundii, SS2; and E. sakazakii, SS1) and on one or two sampling dates. The greatest diversity of bacterial species was registered for SS1, with 7 of the 10 identified species (E. coli, K. cryocrescens, E. agglomerans,
Según el análisis global del periodo estudiado, PM2 presentó las mayores concentraciones promedio de coliformes (CT, $3.23 \times 10^{7}$ UFC $100 \mathrm{~mL}^{-1}$; CF, $1.77 \times$ $10^{7} \mathrm{UFC100} \mathrm{mL}^{-1}$ ) y PM5 las menores (CT, $2.8 \times$ $10^{4} \mathrm{UFC} 100 \mathrm{~mL}^{-1}$; CF, $5.4 \times 10^{3} \mathrm{UFC} 100 \mathrm{~mL}^{-1}$ ) (fig. 3). El análisis estadístico mostró diferencias significativas para julio (CT, $P=0.0001 ; \mathrm{CF}, P=0.0037)$ y $\mathrm{PM} 2(\mathrm{CT}, P=$ 0.0007 ; $\mathrm{CF}, P=0.0257)$. Las reducciones porcentuales promedio de las concentraciones de coliformes por segmento de la sección del canal de drenaje analizada (i.e., PM1 a PM2, PM2 a PM3, PM3 a PM4 y PM4 a PM5) fueron $-223 \%$, $59 \%, 37 \%$ y $62 \%$ para CT y $-700 \%, 59 \%, 30 \%$ y $60 \%$ para $\mathrm{CF}$, respectivamente, donde los valores negativos representan incrementos. Por otra parte, al analizar los porcentajes de reducción mensuales y considerando el primer (PM1) y el último (PM5) punto de muestreo, se observó una clara tendencia hacia la disminución en la concentración de coliformes (fig. 2). Se encontraron diferencias estadísticas en 7 de los 10 meses muestreados $(P<0.05)$. Los valores de la mediana y el promedio de los porcentajes de remoción fueron 
C. amalonaticus, H. alvei, E. aerogenes, and E. sakazakii), whereas the lowest diversity was found for SS3, with 4 of the 10 identified bacterial species (E. coli, K. cryocrescens, E. agglomerans, and C. amalonaticus).

The measured physicochemical water parameters varied with SS (fig. 3); however, the measured variables did not show significant differences $(P>0.05)$ between SS. The correlation analysis between the average coliform concentrations and the physicochemical variables showed a positive correlation with temperature (TC, $r=0.905, P=0.034$; $\mathrm{FC}, r=0.900, P=0.037)$ and a negative correlation with $\% \mathrm{DO}$ (TC, $r=-0.939, P=0.017$; FC $, r=-0.947, P=0.014$ ) (fig. 3).

\section{DISCUSSION}

The large variability observed in the coliform concentrations for each SS analyzed is explained by input point sources of household sewage from human settlements near the studied area. Specifically, SS2 is associated with a steady inflow of domestic wastewater just $6 \mathrm{~m}$ upstream from the sampling point, which was identified as the zone with the highest population density in the studied area (fig. 1). The same was registered for SS3, where a permanent entry of residual wastewater was located $6 \mathrm{~m}$ upstream from this point; SS3 has a lower population density than SS2, which is consistent
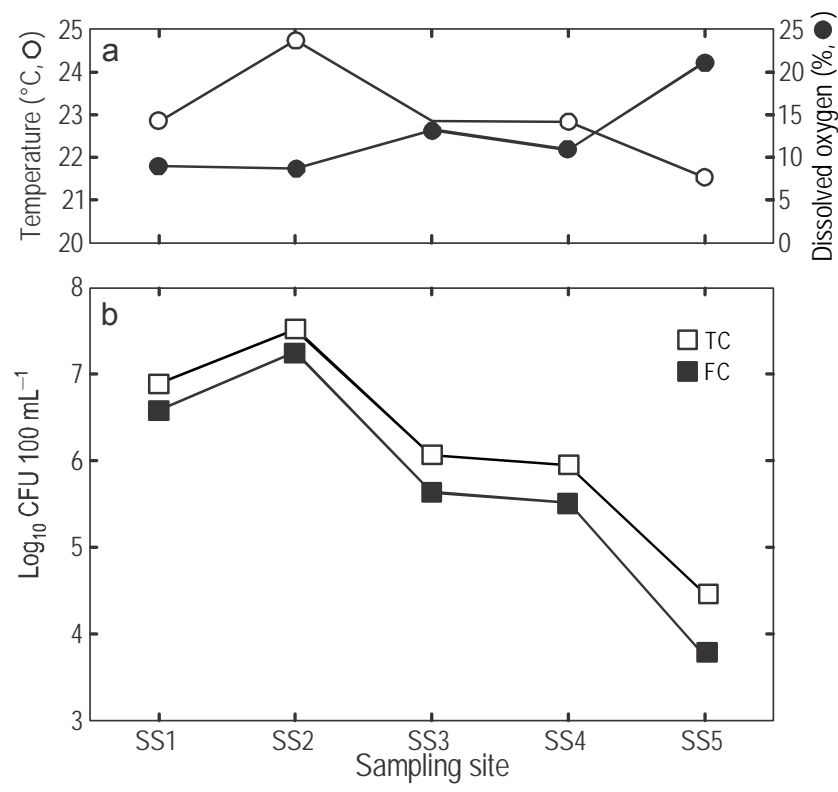

Figure 3. (a) Mean temperature and dissolved oxygen percent saturation values. (b) Mean total coliform (TC) and fecal coliform (FC) concentrations at the sampling sites (SS).

Figura 3. (a) Valores promedio de temperatura y porcentaje de saturación de oxígeno disuelto. (b) Concentraciones promedio de coliformes totales (TC) y coliformes fecales (FC) en los puntos de muestreo (SS).
$96 \%$ y $87 \%$ para CT y $98 \%$ y $85 \%$ para CF, respectivamente. Estos resultados correspondieron a disminuciones de 2.42 (CT) y 2.84 (CF) unidades logarítmicas en la concentración de coliformes a lo largo de la sección del canal de drenaje analizada (figs. 2, 3).

Se identificaron 127 cepas bacterianas, que correspondieron a Escherichia coli (67.7\%), Kluyvera cryocrescens (10.2\%), Enterobacter agglomerans (6.3\%), Citrobacter amalonaticus (3.9\%), grupo Serratia liquefaciens (3.1\%), Hafnia alvei (2.4\%), Enterobacter aerogenes (2.4\%), Serratia odorifera (1.6\%), Citrobacter freundii (1.6\%) y Enterobacter sakazakii (0.8\%). En general, no se registraron tendencias que relacionaran la presencia de alguna especie bacteriana con el mes de muestreo; sin embargo, E. coli fue la única bacteria identificada en las muestras de agua de todos los PM y meses muestreados. El resto de las bacterias no fueron detectadas en al menos un PM o mes muestreado. En particular, tres bacterias sólo se encontraron en un PM (S. odorifera, PM4; C. freundii, PM2; y E. sakazakii, PM1) y en una o dos fechas de muestreo. La mayor diversidad de especies bacterianas fue registrada para PM1, con 7 de las 10 especies identificadas (E. coli, K. cryocrescens, E. agglomerans, C. amalonaticus, H. alvei, E. aerogenes y E. sakazakii), y la menor diversidad fue registrada para PM3, con 4 de las 10 especies identificadas (E. coli, $K$. cryocrescens, E. agglomerans y C. amalonaticus).

Las mediciones de los parámetros fisicoquímicos del agua variaron con el PM (fig. 3), pero no se observaron diferencias estadísticas $(P>0.05)$ entre los $\mathrm{PM}$. El análisis de correlación entre las concentraciones promedio de coliformes y las variables fisicoquímicas evidenció una correlación positiva con la temperatura (CT, $r=0.905, P=0.034$; CF, $r=0.900, P=0.037)$ y una correlación negativa con el \%OD (CT, $r=-0.939, P=0.017$; CF, $r=-0.947, P=0.014$ ) (fig. 3).

\section{DISCUSIÓN}

La gran variabilidad observada en las concentraciones de coliformes para cada PM analizado es explicada por las fuentes puntuales de ingreso de agua residual doméstica de los asentamientos humanos en las inmediaciones del área de estudio. Específicamente, PM2 está asociada a una entrada constante de aguas residuales domésticas ubicada a sólo $6 \mathrm{~m}$ corriente arriba del punto; la zona alrededor de PM2 tiene la mayor densidad poblacional del área de estudio (fig. 1). Lo mismo fue registrado para PM3, donde se identificó una entrada permanente de agua residual doméstica a $6 \mathrm{~m}$ de distancia corriente arriba de este punto; la zona alrededor de PM3 tiene una menor densidad poblacional que aquella en torno a PM2, lo cual resulta consistente con las menores concentraciones de CT y CF en relación con PM2 (figs. 1, 2). Las menores concentraciones de CT y CF en PM5 mostraron que este punto prácticamente no recibió entradas de aguas residuales domésticas y las entradas cercanas a ese punto 
with the lower concentrations of TC and FC relative to SS2 (figs. 1, 2). The lowest concentrations of TC and FC at SS5 showed that this sampling point practically did not receive domestic sewage inputs and nearby entries were derived from rainfall runoff and irrigation water (figs. 1, 2).

Our results indicate the negative impact of anthropogenic activities on the water quality of the La Michoacana drain. Several reports have shown the environmental damage and health risk associated with the discharge of residual wastewater into water bodies worldwide (e.g., Opisa et al. 2011, Bagordo et al. 2012, Matano et al. 2013, Riera et al. 2013 ). In $1997,75 \%$ of the water and $72 \%$ of the mollusk samples obtained from two Sinaloan lagoons (Bahía de Altata and Ensenada El Pabellon) presented TC and FC contents above the Official Mexican Norm (NOM-113-SSA11994), making the mollusks unsuitable for consumption (Haws et al. 2006). In 2004, 28\% of the migrant farmworkers who arrived in Sinaloa were affected by infectious diseases, probably associated with the consumption of contaminated water and food (Ramírez-Romero et al. 2006).

The highest concentrations of TC and FC in the samples obtained from SS1-4 were registered in June and July. This phenomenon may be associated with a concentration effect, because during this period, the habitual regional increase in temperature initiated, and there was no rainfall and irrigation was not allowed. Thus, a continuous stream of water along the drain was not available and SS5 was dry from June to August. Previous studies have shown that precipitation can drag coliform bacteria from adjacent areas to the drain (Hathaway et al. 2011). This partly explains the increased coliform concentrations registered for SS5 in September, month in which Hurricane Manuel brought extremely heavy rains to the area (fig. 2). On the other hand, water samples collected during the months of the lowest water flow (June to August) showed visually higher turbidity. Kadlec and Wallace (2009) reported that UV light from solar radiation can affect the survival of bacteria in residual water of a surface wetland, and the size of the particles suspended in the water plays an important role in determining this; hence, increased water turbidity favors higher coliform concentrations (figs. 2, 3). The density of Typha domingensis plants on the bottom of the drain varied and water was exposed to air and direct sunlight along several subsections of the ditch; therefore, the impact of photo-oxidation on the reduction of $\mathrm{TC}$ and FC cannot be discarded.

The removal of pathogenic organisms is one of the many benefits provided by wetlands (Vacca et al. 2005). Our removal percentages coincide with those registered for both natural and artificial wetlands (Hinds et al. 2002, Kadlec and Wallace 2009, Lekeufack et al. 2012), as well as with the decrease in the range of 2 to 3 logarithmic units of coliform bacteria and E. coli (Azaizeh et al. 2012, Rühmland and Barjenbruch 2012). Nevertheless, despite the good reduction in coliform bacteria registered, the levels for $91.49 \%(43 / 47)$ of the analyzed samples were outside the limits established derivaron de aguas de riego de cultivos cercanos y aguas pluviales (figs. 1, 2).

Nuestros resultados demuestran el impacto negativo de las actividades antropogénicas sobre la calidad del agua del canal de drenaje La Michoacana. Diferentes investigaciones han demostrado el daño ambiental y el riesgo para la salud que causan las descargas de aguas residuales a los cuerpos de agua en varias partes del mundo (e.g., Opisa et al. 2011, Bagordo et al. 2012, Matano et al. 2013, Riera et al. 2013). En 1997, el $75 \%$ de las muestras de agua y el $72 \%$ de las muestras de moluscos obtenidas de la bahía de Altata y Ensenada El Pabellón (Sinaloa) presentaron contenidos de CT y CF por encima de la norma Mexicana (NOM-113SSA1-1994), lo cual provocó que los moluscos fueran inadecuados para el consumo (Haws et al. 2006). En 2004, el 28\% de los trabajadores agrícolas migrantes que arribaron a Sinaloa se vieron afectados por enfermedades infecciosas, probablemente asociados al contacto con agua y alimentos contaminados (Ramírez-Romero et al. 2006).

Las mayores concentraciones de CT y CF en las muestras obtenidas de PM1-4 fueron registradas durante junio y julio. Este fenómeno puede asociarse a un efecto de concentración, ya que durante ese periodo inició el incremento habitual de las temperaturas en la región, no se presentaron lluvias y los riegos agrícolas no se permitían. Por tanto, no hubo flujo continuo de agua a lo largo del canal de drenaje y PM5 permaneció seco durante los muestreos de junio a agosto. Estudios previos han mostrado que las lluvias pueden arrastrar coliformes presentes en zonas aledañas al canal (Hathaway et al. 2011). Esto, en parte, explicaría el aumento registrado en PM5 durante septiembre, mes durante el cual la precipitación fue muy alta debido al huracán Manuel (fig. 2). Por otro lado, las muestras de agua obtenidas durante los meses de menor flujo de agua (junio a agosto) presentaron visualmente mayor turbidez. Kadlec y Wallace (2009) registraron que la luz UV de la radiación solar puede afectar la supervivencia de las bacterias en el agua residual de un humedal de flujo superficial y el tamaño de las partículas suspendidas en el agua son un factor determinante; por lo tanto, la alta turbidez favorece el incremento en las concentraciones de coliformes (figs. 2, 3). La densidad poblacional de Typha domingensis en la sección del canal de drenaje varió y el agua estuvo expuesta al aire y a la luz solar directa en varias subsecciones del canal; por ende, el impacto de la fotooxidación sobre la disminución de CT y CF no puede descartarse.

Entre los múltiples beneficios que los humedales proveen se encuentra la remoción de organismos patógenos (Vacca et al. 2005). Los porcentajes de reducción de CT y CF obtenidos en este trabajo son similares a los registrados tanto para humedales naturales como artificiales (Hinds et al. 2002, Kadlec y Wallace 2009, Lekeufack et al. 2012), así como la disminución en el rango de 2 a 3 unidades logarítmicas de coliformes y E. coli (Azaizeh et al. 2012, Rühmland y Barjenbruch 2012). Sin embargo, aún con la buena reducción de coliformes señalada, los niveles encontrados en el 91.49\% 
by Official Mexican Norm NOM-001-ECOL-1996 (issued by the Mexican Ministry of the Environment and Natural Resources [SEMARNAT], Mexico): the monthly and daily average fecal coliforms for household wastewater discharges in national assets and discharges poured to ground (use in agricultural irrigation) must be less than or equal to 1000 and $2000 \mathrm{MPN} 100 \mathrm{~mL}^{-1}$ (MPN, most probable number), respectively. Only the samples collected at SS4 in November and at SS5 in April, May and November complied with this norm (fig. 2). These last four mentioned samples $(8.51 \%$, 4/47) also met the provisions in norm NOM-003-ECOL-1997 for treated wastewater reused in public services with occasional or indirect contact (maximum $1000 \mathrm{FC} 100 \mathrm{~mL}^{-1}$ ), whereas only 4.25\% (2/47) of the samples (i.e., SS5 in April and May) complied with the norm for the reuse of water in direct contact services (maximum of $240 \mathrm{FC} 100 \mathrm{~mL}^{-1}$ ) (fig. 2). In general, our FC values did not comply with the guidelines established by either the US Environmental Protection Agency, that is, values ranging from 0 (e.g., unrestricted urban use and impoundments) to $200 \mathrm{CFU} 100 \mathrm{~mL}^{-1}$ (e.g., restricted urban use and agricultural use for non-food crops) (EPA 2012), or the World Health Organization for recycled water used for irrigation of edible fresh agricultural products ( $\leq 1000 \mathrm{CFU} 100 \mathrm{~mL}^{-1}$ ) (Ayres and Mara 1996).

According to our results, the La Michoacana drain had a positive effect on the removal of coliform bacteria, as the registered percentages were higher than $90 \%$ in $80 \%$ of the sampled months. Lower bacterial removal occurred in June and March (fig. 3). The June result may be attributed to the following: the drain is fed mainly by domestic wastewater with high coliform concentrations, the decrease in the distance travelled by the stream, the intermittent flow between SS1 and SS4, and the fact that SS5 was dry. On the other hand, the lower removal in March could be associated with the drain dredging performed by the authorities as part of the preparation for the rainy season, which eliminated the vegetation, mainly dominated by $T$. domingensis. Despite the events that occurred during our study period, some unexpected (i.e., prolonged drought, restricted irrigation, and Hurricane Manuel) and others programmed (e.g., drain dredging), the remedial effect of the drain was established based on the significant differences registered between SS1 and SS5 $(n=7)$, which occurred independently of the sample resolution (sample collection over 10 months).

The reduction of bacterial contamination (TC and FC) along the drain could be associated with the interaction of chemical, physical, and biological processes. In particular, the negative correlation between the coliform concentrations and $\% \mathrm{DO}$ indicates the importance of aerobic conditions in the removal of bacteria (fig. 3). Previous studies have shown that the distance travelled by water in the wetland is very important for the mechanisms involved in the removal of microorganisms from the water column (e.g., sedimentation, filtration, physical entrapment, and predation), which are also influenced by the water residence time and speed of the water
(43/47) de las muestras analizadas estuvieron fuera de lo que establece la Norma Oficial Mexicana NOM-001-ECOL-1996 (expedida por la Secretaría de Medio Ambiente y Recursos Naturales, SEMARNAT): el promedio mensual diario de coliformes fecales para descargas de aguas residuales en bienes nacionales así como las descargas vertidas a suelo (uso en riego agrícola) debe ser menor o igual que $1000 \mathrm{y}$ 2000 NMP $100 \mathrm{~mL}^{-1}$ (NMP, número más probable), respectivamente. Solamente las muestras recolectadas en PM4 en noviembre y en PM5 en abril, mayo y noviembre cumplieron con esta norma (fig. 2). Éstas últimas cuatro muestras $(8.51 \%, 4 / 47)$ también cumplieron con lo establecido en la norma NOM-003-ECOL-1997 para aguas residuales tratadas que se reutilizan en servicios al público con contacto ocasional o indirecto (máximo de $1000 \mathrm{CF} 100 \mathrm{~mL}^{-1}$ ), mientras que sólo el 4.25\% (2/47) de las muestras (i.e., PM5 en abril y mayo) cumplieron con lo establecido por la misma norma para el reúso de agua en servicios con contacto directo (máximo de $240 \mathrm{CF} 100 \mathrm{~mL}^{-1}$ ) (fig. 2). En general, nuestros valores de CF también estuvieron fuera tanto de los lineamientos establecidos por la Agencia de Protección Ambiental de Estados Unidos, es decir, valores que van de 0 (e.g., usos urbanos de libre disposición y embalses) a $200 \mathrm{UFC} 100 \mathrm{~mL}^{-1}$ (e.g., uso urbano restringido y uso agrícola para cultivos no alimenticios) (EPA 2012), como los establecidos por la Organización Mundial de la Salud para el agua reciclada utilizada para el riego de los productos agrícolas frescos comestibles $\left(\leq 1000\right.$ UFC $\left.100 \mathrm{~mL}^{-1}\right)$ (Ayres and Mara 1996).

De acuerdo con nuestros resultados, el canal de drenaje agrícola La Michoacana tuvo un efecto positivo en la remoción de coliformes, ya que los porcentajes registrados fueron mayores que el $90 \%$ en el $80 \%$ de los meses muestreados. La menor remoción se presentó en junio y marzo (fig. 3). El resultado de junio posiblemente se debe a que el canal de drenaje se alimentó principalmente de agua residual doméstica con alta concentración de coliformes, a la disminución en la distancia que recorre el agua, al flujo intermitente entre PM1 y PM4, y a que PM5 estuvo seco. Los resultados de marzo podrían deberse a que las autoridades realizaron limpieza del canal como parte de la preparación para la temporada de lluvias y eliminaron gran parte de la vegetación, principalmente dominada por T. domingensis. A pesar de los eventos ocurridos durante el periodo de estudio, algunos inusuales (i.e., sequía prolongada, restricción en los riegos agrícolas y huracán Manuel) y otros programados (e.g., limpieza del canal de drenaje), el efecto remediador del canal pudo establecerse a partir de las diferencias significativas observadas entre PM1 y PM5 $(n=7)$, que ocurrieron independientemente de la resolución del muestreo (muestras distribuidas a lo largo de 10 meses).

La disminución de la contaminación bacteriana (CT y CF) a lo largo del canal de drenaje puede asociarse a la interacción de procesos físicos, químicos y biológicos. En particular, la correlación negativa entre la concentración de 
flow (Kadlec and Wallace 2009, Hathaway et al. 2011). Predation of pathogenic bacteria by other microorganisms (e.g., protozoa) is also important for water quality improvement in remediation systems (Vacca et al. 2005). Likewise, the presence of plant species in surface wetlands has proven to be an important factor in the removal of coliform bacteria (Karim et al. 2008, Lekeufack et al. 2012, Abou-Elela et al. 2013), involving processes such as filtration, biofilm formation associated with released photosynthates and organic compounds, the release of compounds that affect bacterial viability, and the absorption of nutrients in the surrounding medium, among others (Kadlec and Wallace 2009, Karim et al. 2008). Vymazal (2013) reported that the most common plants in wetlands (natural or constructed) belong to the genera Typha, Scirpus (Schoenoplectus), Phragmites, Juncus, and Eleocharis, and specifically for Central and South America, T. domingensis, dominant species along La Michoacana drain.

Coliform bacteria are part of the intestinal flora of humans and warm-blooded animals. Their presence in aquatic environments is an indicator of fecal contamination, mainly of bacterial origin; however, they may also be of environmental origin (occurring in air, soil, and surface water). The coliform bacteria identified in this study have been previously isolated from aquatic environments (McMahan et al. 2012, Sidhu et al. 2012, Barrera-Escorcia et al. 2013). They have been associated with the development of gastrointestinal diseases and urinary tract infections, representing potential pathogenic agents for humans, especially children and people with weakened immune systems, and in general people living in areas without access to clean water or adequate sanitation (Sidhu et al. 2012). A search in Current Contents Connect (Thomson Reuters) until July 2014 showed that the genera Escherichia, Enterobacter, Citrobacter, and Serratia have been commonly found in wetlands and wastewater drains, but not Kluyvera and Hafnia, which in this study represented $10.25 \%$ and $2.40 \%$, respectively, of isolates. Furthermore, the presence of coliform bacteria in water samples has been used as an indicator of the presence of other pathogens (e.g., viruses, parasites) related to watertransmitted diseases (Kadlec and Wallace 2009). In this study, the identification of these organisms and species of Salmonella, Shigella, and Vibrio was not considered; therefore, their presence is not discarded in the $\mathrm{La}$ Michoacana drain.

In the analyzed water samples, the concentrations of coliform bacteria (TC and FC) were correlated with temperature and $\% \mathrm{DO}$ variables. Coliforms can grow in natural surface water due to the large amount of organic matter and high temperatures (Kadlec and Wallace 2009). Our research showed high coliform concentrations during the hottest months (June to August) (fig. 2) and at the SS with the highest average water temperatures (SS1-2) (fig. 3). Kadlec and Wallace (2009) suggested that cold temperatures affect the survival rate of bacteria that are prevalent in warm-blooded coliformes y el \%OD sugiere la importancia de condiciones aeróbicas en la remoción de las bacterias (fig. 3). En estudios previos se ha demostrado que la distancia que recorre el agua en los humedales es muy importante para los mecanismos de remoción de microorganismos de la columna de agua (e.g., sedimentación, filtración, atrapamiento físico y predación), que también son influenciados por el tiempo de residencia y la velocidad del flujo del agua (Kadlec y Wallace 2009, Hathaway et al. 2011). La predación de bacterias patógenas por otros organismos (e.g., protozoarios) también es importante para mejorar la calidad del agua en los sistemas de remediación (Vacca et al. 2005). De igual manera, la presencia de especies vegetales en los humedales de flujo superficial ha mostrado ser un factor muy importante en la remoción de coliformes (Karim et al. 2008, Lekeufack et al. 2012, Abou-Elela et al. 2013), puesto que se involucran procesos como la filtración, la formación de biopelículas asociada a la liberación de fotosintatos y compuestos orgánicos, la liberación de compuestos que afectan la viabilidad bacteriana, la absorción de nutrientes en el medio circundante, entre otros (Kadlec y Wallace 2009, Karim et al. 2008). Vymazal (2013) registró que las plantas más comunes en los humedales, naturales o construidos, pertenecen a los géneros Typha, Scirpus (Schoenoplectus), Phragmites, Juncus y Eleocharis, y específicamente para América Central y del Sur a T. domingensis, que fue la especie dominante a lo largo del canal de drenaje La Michoacana.

Las bacterias coliformes forman parte de la flora intestinal de los humanos y animales de sangre caliente. Su presencia en ambientes acuáticos es un indicador de contaminación de origen fecal, principalmente bacteriana; sin embargo, los coliformes también pueden tener un origen ambiental porque están presentes en el aire, suelo y agua superficial. Los coliformes identificados en este estudio han sido aislados previamente de ambientes acuáticos (McMahan et al. 2012, Sidhu et al. 2012, Barrera-Escorcia et al. 2013). Se les ha relacionado con el desarrollo de enfermedades gastrointestinales e infecciones de vías urinarias, por lo cual representan agentes potencialmente patógenos para los humanos, principalmente la población infantil, las personas con el sistema inmune comprometido $\mathrm{y}$, en general, las personas que habitan en regiones sin acceso a agua potable o saneamiento adecuado (Sidhu et al. 2012). Una búsqueda en Current Contents Connect (Thomson Reuters) hasta julio de 2014 mostró que los géneros Escherichia, Enterobacter, Citrobacter y Serratia han sido registrados comúnmente en humedales y canales de desagüe, pero no Kluyvera y Hafnia, que en este estudio representaron el $10.25 \%$ y $2.40 \%$, respectivamente, de las cepas aisladas. Por otro lado, la presencia de coliformes en muestras de agua ha sido considerada como un indicador de la presencia de otros patógenos (e.g., virus, parásitos) relacionados con enfermedades transmitidas por agua (Kadlec y Wallace 2009). En este estudio, la identificación de dichos organismos y de especies de Salmonella, Shigella y Vibrio no 
animals, such as coliforms; thus, the best survival conditions for the drain bacteria were at the SS with near optimum temperatures $\left(37^{\circ} \mathrm{C}\right)$. The positive correlation with temperature did not coincide with that reported by Riera et al. (2013), who analyzed the effect of physicochemical water variables on the presence of total coliforms in a coastal area receiving domestic wastewater discharges and brine, and found a negative correlation with temperature. On the other hand, it has been reported that a greater amount of dissolved oxygen favors the photo-oxidation and disinfection process (Kadlec and Wallace 2009). As in our research, Cheng et al. (2013) found a negative correlation between the levels of dissolved oxygen and the density of $E$. coli; wetland aeration favored the development of $E$. coli predators and promoted the photooxidative damage. In Daya Bay (China), the presence of bacteria and microalgae were mainly associated with the concentration of nutrients (nitrates, ammonia, and silicates), which are highly impacted by anthropogenic activities, whereas dissolved oxygen showed a lower correlation $(\mathrm{Wu}$ et al. 2014). In regard to $\mathrm{pH}$, the values obtained for the samples from all the SS comply with the guidelines given in NOM-001-ECOL-1996 ( $\mathrm{pH}=5-10)$, which establishes the permissible maximum limits of pollutants in wastewater discharges in national waters. The absence of correlation of $\mathrm{pH}$ and salinity with coliform concentration agrees with data reported by Riera et al. (2013). In contrast, relatively high $\mathrm{pH}$ values, associated with a high decay of organic matter, favored the denitrification process in the Urías coastal lagoon system, Gulf of California, Mexico (Ochoa-Izaguirre and Soto-Jiménez 2013), as well as the presence of microalgae and bacteria in Daya Bay (Wu et al. 2014).

La Michoacana, located in an area of intensive agriculture and flanked by a rural community, drains water with a high content of total and fecal coliforms. The levels in $91.49 \%$ of the water samples exceeded the limits established by both Mexican and international guidelines for the content of these microorganisms, showing the severity of the pollution. Interestingly, the performance of this drain improved water quality, reducing the TC by $96 \%$ and the FC by $98 \%$. However, the microbiological quality of water leaving the drain must be improved before being reused or deposited in coastal water bodies, because under the present conditions, these discharges are a source of pollution threatening the health of the ecosystem, including humans. The results of this research indicate the participation of diverse physical, chemical, and biological processes in the remediation of the bacterial contamination in the La Michoacana drain, and suggest that the remediation effect of drainage ditches, which are similar to surface wetlands, could be improved with proper management and maintenance. Further studies, such as metagenomic analysis, are needed to establish the presence of microbial consortiums (e.g., algae, bacteria, fungi, and phages) in the drain, and their participation in the sedimentwater-plant system and in the remediation of the bacterial contamination of the water in this type of system. fue considerada; por lo tanto, no se descarta su presencia en el canal de drenaje La Michoacana.

En las muestras de agua analizadas, las concentraciones de coliformes ( $\mathrm{CT}$ y $\mathrm{CF}$ ) se correlacionaron con las variables temperatura y \%OD. Los coliformes pueden crecer en aguas superficiales naturales debido a la gran cantidad de materia orgánica y a las altas temperaturas (Kadlec y Wallace 2009). En nuestro trabajo, la mayor concentración de coliformes se registró para los meses con la temperatura ambiental más alta (junio a agosto) (fig. 2) y para los PM con temperatura promedio del agua más alta (PM1-2) (fig. 3). Kadlec y Wallace (2009) mencionaron que las temperaturas frías afectan la supervivencia de organismos que se originan en animales de sangre caliente, como los coliformes; esto indica que la mejor condición de supervivencia para las bacterias se encontró en los PM con temperatura del agua cercana a su óptima de crecimiento $\left(37^{\circ} \mathrm{C}\right)$. La correlación positiva entre la concentración de coliformes y la temperatura no coincidió con la registrada por Riera et al (2013), quienes analizaron el efecto de las variables fisicoquímicas del agua sobre la presencia de coliformes totales en una zona costera con descargas de aguas residuales domésticas y salmuera, y encontraron una correlación negativa. En cuanto al \%OD, se ha registrado que una mayor cantidad de oxígeno disuelto favorece la fotooxidación y, consecuentemente, el proceso de desinfección (Kadlec y Wallace 2009). Al igual que en nuestro trabajo, Cheng et al. (2013) encontraron una correlación negativa entre los niveles de oxígeno disuelto y la densidad de E. coli; la aireación del humedal favoreció el desarrollo de depredadores de E. coli y promovió el daño fotooxidativo. En la bahía de Daya (China), la presencia de bacterias y microalgas estuvo asociada a la concentración de nutrientes (nitratos, amonio y silicatos), los cuales son altamente impactados por las actividades antropogénicas, mientras que el oxígeno disuelto tuvo una menor correlación (Wu et al. 2014). En el caso del $\mathrm{pH}$, los valores encontrados en todos los PM del canal de drenaje cumplen con lo establecido por la norma NOM-001-ECOL-1996 (pH = 5-10), que establece los límites máximos permisibles de contaminantes en las descargas de aguas residuales en aguas y bienes nacionales. La ausencia de correlación del $\mathrm{pH}$ y de la salinidad con el contenido de coliformes coincide con lo registrado por Riera et al. (2013). En contraste, los valores relativamente altos del pH, asociados a una alta descomposición de materia orgánica, favorecieron el proceso de desnitrificación en el sistema lagunar de Urias, golfo de California, México (Ochoa Izaguirre y Soto-Jiménez 2013), así como la presencia de microalgas y bacterias en la bahía Daya, China (Wu et al. 2014).

El canal de drenaje La Michoacana, ubicado en una zona de agricultura intensiva y flanqueado por una comunidad rural, conduce agua con un alto contenido de CT y CF. El $91.49 \%$ de las muestras de agua analizadas no cumplió con los límites establecidos por las normas oficiales mexicanas ni los lineamientos internacionales para el contenido de estos 


\section{ACKNOWLEDGMENTS}

This work was supported by the National Council for Science and Technology, Mexico (CONACYT I010/214/2012), and the German Academic Exchange Service (DAAD Pestmex U455D813 KTR). The authors thank Seifeddine Jomaa for his collaboration during the drain selection, definition of sampling sites, and discussion of methodological strategies, and Ignacio Osuna-Ramírez for his help during data analysis.

\section{REFERENCES}

Abou-Elela SI, Golinelli G, Saad El-Tabl A, Hellal MS. 2013. Treatment of municipal wastewater using horizontal flow constructed wetlands in Egypt. Water Sci. Technol. 69: 38-47.

Alexander S, McInnes R. 2012. Los beneficios de restauración de humedales. Notas de Información Científica y Técnica de Ramsar No. 4. Ramsar Secretariat, Gland, Switzerland, pp. 1-22.

[APHA, AWWA, WEF] American Public Health Association, American Water Works Association, Water Environment Federation. 2005. Standard Methods for the Examination of Water and Wastewater. 21st ed. American Public Health Association, Washington DC, $55 \mathrm{pp}$.

Ayres RM, Mara DD. 1996. Analysis of wastewater for use in agriculture: A laboratory manual of parasitological and bacteriological techniques. World Health Organization, Finland and Geneva, $31 \mathrm{pp}$.

Azaizeh H, Linden KG, Barstow C, Kalbouneh S, Tellawi A, Albalawneh A, Gerchman Y. 2012. Constructed wetlands combined with UV disinfection systems for removal of enteric pathogens and wastewater contaminants. Water Sci. Technol. 67: 651-657.

Bagordo F, Serio F, Lugoli F, Grassi T, Idolo A, Gabutti G, De-Dono A. 2012. Phenotypic characterization of culturable marine luminous bacteria isolated from coastal waters of the southern Adriatic Sea (Otranto, Italy). Cienc. Mar. 38: 599-608. http://dx.doi.org/10.7773/cm.v38i4.2119

Barrera-Escorcia G, Fernández-Rendón CL, Wong-Chang I, Ramírez-Romero P. 2013. La sensibilidad del grupo coliforme como indicador de la presencia de enterobacterias patógenas en cuatro cuerpos acuáticos de México. Hidrobiológica 23: 87-96.

[CONAGUA] Comisión Nacional del Agua. 2011. Infraestructura hidráulica. In: Estadísticas del Agua en México, edición 2011. CONAGUA, México, pp. 57-78.

[CONAPESCA] Comisión Nacional de Acuacultura y Pesca. 2012. Anuario Estadístico de Acuacultura y Pesca 2011. Mazatlán, Sinaloa, México, 305 pp.

Cupul-Magaña L, Mösso-Aranda C, Sánchez-Arcilla A, SierraPedrico J, Fermán-Almada J, Romero I, Falco S. 2006. Distribución bacteriológica en el agua de mar en la Bahía Cullera, España. Cienc. Mar. 32: 311-318.

Cheng J, Niu S, Kim Y. 2013. Relationship between water quality parameters and the survival of indicator microorganisms Escherichia coli in a stormwater wetland. Water Sci. Technol. 68: $1650-1656$.

[EPA] Environmental Protection Agency. 2012. Guidelines for Water Reuse. USAID and CDM Smith Inc., USA, 643 pp.

Escobedo-Urías D, Hernández-Real MT, Herrera-Moreno N, UlloaPérez AE, Chiquete-Ozono Y. 1999. Calidad bacteriológica del sistema lagunar de San Ignacio-Navachiste, Sinaloa. Ciencia y Mar 9: 17-27. microorganismos, lo cual muestra la severidad de la contaminación. De manera interesante, el funcionamiento de este canal reduce hasta en un $96 \%$ los CT y hasta en un $98 \%$ los $\mathrm{CF}$, mejorando considerablemente la calidad del agua que conduce. Sin embargo, la calidad microbiológica del agua a la salida del canal debe mejorarse antes de ser reutilizada o depositada en cuerpos de agua costeros, ya que en las condiciones actuales, estas descargas son una fuente de contaminación que pone en riesgo la salud del ecosistema y humana. Los resultados del presente trabajo indican la participación de diversos procesos físicos, químicos y biológicos en la remediación de la contaminación bacteriana del canal de drenaje La Michoacana, además sugieren que este tipo de canales agrícolas, con características similares a humedales de flujo superficial, pueden incrementar su efecto remediador con un mantenimiento apropiado. Estudios más profundos, como el análisis metagenómico, permitirán determinar la presencia de consorcios microbianos (e.g., algas, bacterias, fagos y hongos) en el canal y su participación en el sistema aguasedimento-planta y en la remediación de la contaminación bacteriana en el agua de este tipo de sistema.

\section{AgRADECIMIENTOS}

Esta investigación fue financiada por el Consejo Nacional de Ciencia y Tecnología, México (CONACYT I010/214/ 2012), y el Servicio Alemán de Intercambio Académico (DAAD Pestmex KTR U455D813). Los autores agradecen a Seifeddine Jomaa su colaboración en la selección del canal de drenaje, la definición de los sitios de muestreo, el análisis de estrategias metodológicas y el diseño de gráficos, y a Ignacio Osuna-Ramírez su ayuda en el análisis de datos.

Hathaway JM, Hunt WF, Graves AK, Bass KL, Caldwell A. 2011. Exploring fecal indicator bacteria in a constructed stormwater wetland. Water Sci. Technol. 63: 2707-2712.

Hinds J, Terry D, Brown RR, Burns EHJ. 2002. Reduction of fecal coliform levels in two created wetlands at the Olentangy River Wetland Research Park. Olentangy River Wetland Research Park at the Ohio State University, Annual Report, Columbus, Ohio, pp. 69-72.

Kadlec RH, Wallace SD. 2009. Treatment Wetlands. 2nd ed. Taylor \& Francis Group, Boca Raton, Florida, 1016 pp.

Karim MR, Glenn EP, Gerba CP. 2008. The effect of wetland vegetation on the survival of Escherichia coli, Salmonella typhimurium, bacteriophage MS-2 and polio virus. J. Water Health 6: 167-175.

Lekeufack M, Fonkou T, Pamo TE, Amougou A. 2012. Removal of faecal bacteria and nutrients from domestic wastewater in a horizontal surface flow wetland vegetated with Echinochloa pyramidalis. Afr. J. Environ. Sci. Technol. 6: 337-345.

MacFaddin JF. 2003. Pruebas Bioquímicas para la Identificación de Bacterias de Importancia Clínica. 3rd ed. Médica Panamericana, Argentina, $850 \mathrm{pp}$.

Matano AS, Anyona DN, Owuor PO, Abuom PO, Dida GO, Kapiyo R, Ofulla AVO. 2013. Effects of land use types on the levels of microbial contamination based on total coliform and Escherichia coli counts on the Mara River, East Africa. Afr. J. Trop. Hydrobiol. Fish. 13: 5-11. 
McMahan L, Grunden AM, Devine AA, Sobsey MD. 2012. Evaluation of a quantitative H2S MPN test for fecal microbes analysis of water using biochemical and molecular identification. Water Res. 46: 1693-1704.

Ochoa-Izaguirre MJ, Soto-Jiménez MF. 2013. Evaluation of nitrogen sources in the Urías lagoon system, Gulf of California, based on stable isotopes in macroalgae. Cienc. Mar. 39: 413-430. http://dx.doi.org/10.7773/cm.v39i4.2285

ONU-DAES, UN-water (2014). Decenio Internacional para la Acción "El agua fuente de vida" 2005-2015 [cited May 2014]. Available from: http:/www.un.org/spanish/waterforlifedecade/ quality.shtml.

Opisa S, Odiere MR, Jura WG, Karanja DM, Mwinzi PN. 2011. Faecal contamination of public water sources in informal settlements of Kisumu City, western Kenya. Water Sci. Technol. 66: 2674-2681.

Haws M, Rojas-Umaña A, and Ochoa E. 2006. Salud, Ambiente y Acuicultura en la Costa Pacifica de México. ACRSP, Oregon State University, Corvallis, Oregon, 149 pp.

Pierre H, Finlayson CM. 2011. Wetlands as settings for human health: Incorporating ecosystem services and health impact assessment into water resource management. BioScience 61: 678-688.

Ramírez-Romero SJ, Palacios Nava D, Velazco-Samperio D. 2006. Diagnóstico sobre la condición social de las niñas y niños migrantes internos, hijos de jornaleros agrícolas. Fondo de las Naciones Unidas para la Infancia (UNICEF-México), México, $153 \mathrm{pp}$.

Reinoso R, Torres LA, Bécares E. 2008. Efficiency of natural systems for removal of bacteria and pathogenic parasites from wastewater. Sci. Total Environ. 395: 80-86.

http://dx.doi.org/10.1016/j.scitotenv.2008.02.039
Riera R, Tuya F, Sacramento A, Ramos E, Monterroso Ó, Rodríguez M. 2013. Influence of the combined disposal of sewage and brine on meiofauna. Cienc. Mar. 39: 15-27. http://dx.doi.org/10.7773/cm.v39i1.2162

Rühmland S, Barjenbruch M. 2012. Disinfection capacity of seven constructed wetlands and ponds. Water Sci. Technol. 68: 2111-2117.

[SEDESOL] Secretaría de Desarrollo Social. 2014. Sistema de Apoyo para la Planeación del Programa de Desarrollo para Zonas Prioritarias [cited 23 November 2014]. Available from http://www.microrregiones.gob.mx/catloc/ contenido.aspx?refnac $=250180074$.

[SIAP] Servicio de Información Agroalimentaria y Pesquera. 2014. Anuario Estadístico de la Producción Agrícola [cited 18 July 2014]. Available from: http://www.siap.gob.mx/cierre-de-laproduccion-agricola-por-estado/.

Sidhu JP, Ahmed W, Hodgers L, Toze S. 2012. Occurrence of virulence genes associated with diarrheagenic pathotypes in Escherichia coli isolates from surface water. Appl. Environ. Microb. 79: 328-335.

Vacca G, Wand H, Nikolausz M, Kuschk P, Kästner M. 2005. Effect of plants and filter materials on bacteria removal in pilot-scale constructed wetlands. Water Res. 39: 1361-1373.

Valdés J, Guiñez M, Castillo A, Vega SE. 2014. Cu, Pb, and $\mathrm{Zn}$ content in sediments and benthic organisms from San Jorge Bay (northern Chile): Accumulation and biotransference in subtidal coastal systems. Cienc. Mar. 40: 45-58. http://dx.doi.org/10.7773/cm.v40i1.2318

Vymazal J. 2013. Emergent plants used in free water surface constructed wetlands: A review. Ecol. Eng. 61(B): 582-592.

Wu M-L, Wang Y-T, Wang Y-S, Sun F-L. 2014. Influence of environmental changes on picophytoplankton and bacteria in Daya Bay, South China Sea. Cienc. Mar. 40: 197-210. http://dx.doi.org/10.7773/cm.v40i3.2436

Received August 2014, accepted November 2014. 